\title{
GAS EXCHANGES IN ANNONACEAE SPECIES UNDER DIFFERENT CROP PROTECTIONS ${ }^{1}$
}

\author{
DANIEL BARON², GISELA FERREIRA ${ }^{3}$, JOÃO DOMINGOS RODRIGUES ${ }^{3}$, \\ ANA CLAUDIA MACEDO ${ }^{4}$, AMANDA CRISTINA ESTEVES AMARO ${ }^{4}$
}

\begin{abstract}
This study aims to investigate the gas exchanges of different species of Annonaceae due to environmental variations provided by different types of crop protection. 'Araticum-de-terra-fria', 'araticummirim', 'biribá' and atemoya seedlings were cultived in three different crop protections: nursery, greenhouse and warm house. Gas exchanges were obtained in six plants, from 9:00 am to 11:00 am, with IRGA, LI-6400, at 180 Days After Transplanting. The different types of crop protection had a direct influence on gas exchanges of these species. Thus, nursery provided suitable conditions for 'araticum-de-terra-fria', 'araticum-mirim' and 'biribá', increasing their gas exchanges. To atemoya the best crop protection was the greenhouse.
\end{abstract}

Index terms: Photosynthesis, environmental condition, Annona emarginata, Annona mucosa, Annona squamosa L. x Annona cherimola Mill.

\section{TROCAS GASOSAS EM ESPÉCIES DE ANNONACEAE EM DIFERENTES PROTEÇÕES AMBIENTAIS}

RESUMO - Objetivou-se investigar as trocas gasosas de diferentes espécies Annonaceae em função de variações ambientais proporcionadas por diferentes tipos de cultivos protegidos. Mudas de araticum-de-terrafria, araticum-mirim, biribá e atemoia foram cultivadas em três diferentes condições ambientais: viveiro, casa de vegetação e estufa. As avaliações de trocas gasosas foram feitas com seis plantas, das 9 às $11 \mathrm{~h}$, através do IRGA, LI-6400, aos 180 dias após o transplante. Os diferentes tipos de cultivo tiveram influência direta sobre as trocas gasosas dessas espécies. Assim, o viveiro proporcionou condições mais adequadas para o 'araticum-de-terra-fria', 'araticum-mirim' e 'biribá', incrementando suas trocas gasosas. Já para atemoia, o melhor ambiente de cultivo foi à casa de vegetação.

Termos de indexação: Fotossíntese, condições ambientais, Annona emarginata, Annona mucosa, Annona squamosa L. x Annona cherimola Mill.

\section{INTRODUCTION}

Atemoya (Annona squamosa L. x Annona cherimola Mill.) is a fruit used worldwide in food industry for the production of ice-cream, candies, jams, juices, liqueurs and consumption 'in natura' (SCUC, 2006; TORRES et al., 2009). This hybrid must be propagated by grafting to ensure commercial characteristics (TOKUNAGA, 2005).

According to Kavati; Watanabe (2010), find rootstock resistant to pathogens and that exhibit greater compatibility with atemoya has not been easy, however, Scaloppi Junior (2007) reports that 'araticum-de-terra-fria' [A. emarginata (Schltdl.) H. Rainer "var. terra-fria"] and 'araticum-mirim' [A. emarginata (Schltdl.) H. Rainer "var. mirim"] have tolerance to root rot caused by Phytophthora nicotianeae var. parasitica, Pythium sp. and Rhizoctonia solani, besides being considered for potential use as rootstock (TOKUNAGA, 2005). 'Biribá' [A. mucosa (Bail.) H. Rainer], has been studied to avoid problems with nematode and stemborers, with better adaptation to adverse conditions allowing the expansion of adaptability of scion

\footnotetext{
'(Trabalho 195-13). Recebido em: 15-05-2013. Aceito para publicação em: 28-10-2014. V Congresso Internacional \& Encontro Brasileiro sobre Annonaceae: do gene à exportação (19 a 23 de Agosto de 2013). Botucatu-SP.

${ }^{2}$ Agronomist. Doctor student in Biological Sciences (Botany). Instituto de Biociências, Universidade Estadual Paulista - UNESP, Campus de Botucatu, Departamento de Botânica, Laboratório de Fisiologia Vegetal, District of Rubião Júnior, S/Nº , 18618-970, Botucatu, São Paulo, Brazil. E-mail: agroozzy@yahoo.com.br

${ }^{3}$ Agronomist, Professor. Instituto de Biociências, Universidade Estadual Paulista - UNESP, Campus de Botucatu, Departamento de Botânica, Laboratório de Fisiologia Vegetal, District of Rubião Júnior, S/No ${ }^{\circ}$ 18618-970, Botucatu, São Paulo, Brazil. E-mails: gisela@ibb.unesp.br; mingo@ibb.unesp.br

${ }^{4}$ Biologist. Doctor student in Agronomy (Horticulture), Faculdade de Ciências Agronômicas, Universidade Estadual Paulista - UNESP, Campus de Botucatu, Departamento de Produção Vegetal, Street of José Barbosa de Barros, nº 1780, Botucatu, São Paulo, Brazil. E-mails: amandaamaro@uol.com.br; anamacedo85@gmail.com
} 
(ALMEIDA et al., 2010).

All production of biomass depends on photosynthetic activity of source, and photoassimilation constitutes more than $90 \%$ of the dry material of the plant. A portion of these assimilated is used during the plant growth, becoming biomass, and, another part, is oxidized in respiration and serves as energy source for growth and function of biological processes (PLAXTON; PODESTA et al., 2006).

Metabolic rates of plants are influenced by environmental conditions. They determine rates and proportions of photosynthesis and respiration, eventually even, possibly biological and economic productivity of these plants (VAN DONGEN et al., 2011). Therefore, it becomes increasingly important to study the physiology of source and a way to study it is by measuring gas exchanges.

Species like 'araticum-de-terra-fria', 'araticum-mirim', 'biribá' and atemoya are presented as viable alternatives and successful as rootstocks, in several regions of Brazil. The aim of this study was to evaluate how climate conditions in different types of crop protection affect gas exchanges of 'araticumde-terra-fria', 'araticum-mirim' and 'biribá' species and hybrid atemoya.

\section{MATERIAL E METHODS}

The experiment was conducted in Botucatu, São Paulo, Brazil, 48 24' 35” W, $22^{\circ} 44^{\prime}$ '10” S and $850 \mathrm{~m}$, from February until June 2012. Seeds from 'araticum-de-terra-fria', 'araticum-mirim' and 'biribá' species along with hybrid atemoya were disinfected with sodium hypochlorite (1\%) and CAPTAN ${ }^{\circledR}$ fungicide (DELIOPOULOS et al., 2010). Thereafter, seeds were sown in polystyrene trays filled with vermiculite (BARON et al., 2011), until their emergence. The first fully expanded leaves above the third node of the epicotyls, or third node nomofile, were named seedlings with $\pm 10 \mathrm{~cm}$ in length, and then transplanted to plastic bags with a capacity of $5 \mathrm{dm}^{3}$, containing a mixture of fertile soil texture vermiculite medium texture + coconut fiber medium texture + decomposed pine bark medium texture $(1: 1: 1: 1, \mathrm{v} / \mathrm{v})$. Seedlings were grown with complete nutrient solution diluted to $50 \%$ of its ionic strength, electrical conductivity (EC) of 1.0 miliSiemens $/ \mathrm{cm}^{-1}$ (BARON et al., 2013), applied weekly $300 \mathrm{ml}$ of this solution per pot. Two months after transplanting, seedlings were placed in the treatments for acclimatization.

Treatments consisted of cultivating four different species: 'araticum-de-terra-fria', 'araticummirim', 'biribá' and atemoya under three different conditions of crop protection: Nursery, uncontrolled environmental conditions (control treatment), consisting shaded tunnel (18\% shading) with 622.57 $\mu \mathrm{mol} \mathrm{m} \mathrm{m}^{-2} \mathrm{~s}^{-1}$ light photosynthetic active radiation, anti-UV and black, commonly used by nurseries; Greenhouse, control of environmental conditions, with photosynthetically active radiation of 800 $\mu \mathrm{mol} \mathrm{m} \mathrm{s}^{-2}$ light photosynthetic active radiation (photoperiod $12 \mathrm{~h}$ day / $12 \mathrm{~h}$ night) issued by 22 halogen bulbs with tungsten filament $(37 \mathrm{~W})$ each, $25^{\circ} \mathrm{C} \pm 3^{\circ} \mathrm{C}$ internal temperature and $55-75 \%$ relative humidity; Warm House, uncontrolled environmental conditions, composed of metal structure, 'arc type' with $586.27 \mu \mathrm{mol} \mathrm{m} \mathrm{m}^{-2} \mathrm{~s}^{-1}$ light photosynthetic active radiation covered agricultural plastic film transparent polyethylene with $150 \mu \mathrm{m}$, laterally covered to cooling and natural barrier to allow the entry of insects. Plants were distributed in a complete randomized block, with six replicates per treatment, with one plant each.

Gas exchanges evaluations were performed using Infra Red Gas Analyser - IRGA, LI 6400, LICOR. An evaluation at 180 Days After Acclimatization period from 9:00 am to 11:00 am, on a sunny day. The $\mathrm{CO}_{2}$ concentration reference used during evaluations was the present in the environment, ranging from 380 to $400 \mu \mathrm{mol} \mathrm{CO} \mathrm{mol}^{-1}$. It was evaluated the Net assimilation rate $\left(A, \mu \mathrm{mol} \mathrm{CO} \mathrm{m}^{-2} \mathrm{~s}^{-1}\right)$, transpiration $\left(E, \mathrm{~mol} \mathrm{H}_{2} \mathrm{O} \mathrm{m}^{-2} \mathrm{~s}^{-1}\right)$, stomatal conductance $\left(g_{\mathrm{s}}\right.$, mol $\left.\mathrm{H}_{2} \mathrm{O} \mathrm{m}^{-2} \mathrm{~s}^{-1}\right)$, intercellular $\mathrm{CO}_{2}$ concentration $\left(C_{\mathrm{i}}\right.$, $\left.\mu \mathrm{mol} \mathrm{CO}_{2} \mathrm{~mol} \mathrm{air}^{-1}\right)$ and vapor pressure deficit $\left(\mathrm{V}_{\mathrm{pdL}}\right)$. The water use efficiency $\left(W U E, \mu \mathrm{mol} \mathrm{CO}_{2}\right.$ $\left(\mathrm{mol} \mathrm{H}_{2} \mathrm{O}\right)^{-1}$ ) was determined by the relationship between Net assimilation rate and transpiration, as well as apparent carboxylation efficiency $\left(A / C_{\mathrm{i}}\right)$ was determined by the relationship between $\mathrm{CO}_{2}$ assimilation rate and internal $\mathrm{CO}_{2}$ concentration on leaf.

\section{RESULTS}

Environmental parameters recorded during seedling development are shown in Table 1 and environmental conditions values, at the time of gas exchanges measurement, are shown in Table 2. Thus, among the different crop protection used for seedlings development, warm house was the warmest and the driest environment and the greenhouse provided the mildest conditions. 
Gas exchanges results are shown in Table 2. To 'araticum-de-terra-fria', nursery conditions provided greater $A$, however, $g_{\mathrm{s}}$ was the same among all crop protections, suggesting that stomatal aperture was not the limiting factor, but rather its $A / C_{i}$, which was higher in the nursery, agreeing with the $C_{\mathrm{i}}$ values. The $E$ was also similarly among the conditions, but the $W U E$ was higher in this ambient. In the warm house, this species had lower $A$ and $A / C_{\mathrm{i}}$, however its $E$ was slightly higher, in agreement with its largest $\mathrm{V}_{\mathrm{pdL}}$. To 'araticum-mirim' species, nursery also provided greater $A$, with $g_{\mathrm{s}}$ similar between environments, but, in this case, the $C_{\mathrm{i}}$ also remained unchanged, leading to similar $A / C_{\mathrm{i}}$. The $E, W U E$ and $V_{\text {pdL }}$ were also similar between the evaluated crop protections. To atemoya there was no difference in $A$ and $A / C_{\mathrm{i}}$, but tended to decrease when it was in the warm house. It is also observed that, in this environment, $g_{\mathrm{s}}$ was lower and, consequently, its $E$, leading to increased the $W U E$. Despite no difference was found between treatments, in the greenhouse there was a tendency for higher $A, A / C_{\mathrm{i}}$ and $W U E$. To 'biribá', there were also no significant differences in gas exchanges between the different crop protections. However, spite of warm house trend for higher $A$, the highest $g_{\mathrm{s}}$ allowed higher $E$ and, hence, lower $W U E$. Already in the nursery, the most $A$ was due to higher $A / C_{\mathrm{i}}$, because his $g_{\mathrm{s}}$ was lower, as well as, its $E$ and $V_{\text {pdL }}$ and, therefore, had higher $W U E$.

As in greenhouse temperature and relative humidity were controlled, reflecting in the soil temperature (Table 2), plants submitted to this crop protection presented stable gas exchanges, being neither the largest, nor the smallest among all crop protections, except to atemoya, which was favored in this condition.

\section{DISCUSSION}

In this study, greenhouse was the environment that provided the closest to ideal conditions of temperature and humidity for ' $\mathrm{C} 3$ ' metabolism species, in other words, temperatures around 25$30^{\circ} \mathrm{C}$ and air relative humidity around $55-65 \%$ (DOUBNEROVÁ; RYŠLAVÁ, 2011; LEE et al., 2011). Although greenhouse has provided milder environmental conditions, compared to the other crop protections, this one only favored atemoya gas exchanges. The gas exchanges results in this study are consistent with photosynthetic performances presented by Anonaceous in their evolutionary origin centers. Thereby, the 'biribá', originating from a tropical region (hot and humid), showed more efficient gas exchanges in the nursery, which reflected this condition (MAAS; WESTRA, 1992).

Little is known about the exact origin center of 'araticum-de-terra-fria' and 'araticummirim', because morphological differences could be evidence of different 'taxa', but more studies are needed to confirm this assertion. Moreover, Rainer (2007) published a study about the rearrangement of several taxonomic 'taxa', which synonymize and classify them as Annona emarginata (Schltdl.) H. Rainer. According to Maas; Westra (1992), the Rollinia emarginata (Schltdl.), currently classified as Annona emarginata (Schltdl.) H. Rainer, has origin center predominantly subtropical, but is also found in tropical regions. The results of this study revealed that as 'araticum-mirim', so as 'araticumde-terra-fria', were favoring photosynthetic in the nursery conditions, more like the tropical region, despite 'araticum-de-terra-fria', usually, develops better under cold conditions (TOKUNAGA, 2005).

On the other hand, atemoya, since it is a hybrid developed from a subtropical species (cherimoya) and tropical (sugar-apple) species, has no seasonal origin center defined (DE CASSIA SEFFRIN et al., 2010). Thus, in this study, atemoya adapted better to the conditions of the greenhouse, which presented milder relative humidity and temperatures, as evidenced by high $W U E$ and $A / C_{i}$, so its ideal conditions would be the middle of cherimoya and sugar-apple. However, atemoya grafted on sugarapple kept in root temperature conditions similar to those found in the tropics $\left(25-35^{\circ} \mathrm{C}\right)$ showed similar responses to those obtained by Annonaceae species of tropical origin, and this response is due to the influence of his rootstock (OJEDA et al., 2004b).

Sugar-apple (tropical) and cherimoya (subtropical) species exhibit different behavior in regimes alternating day/night temperature $\left(30^{\circ} / 25^{\circ} \mathrm{C}\right)$, with further development of sugar-apple. Meantime, cherimoya presented lower values of $A$ by reducing the stomatal closure, increased respiration and limit the carboxylation efficiency, when compared with thermal regime $20 / 15^{\circ} \mathrm{C}$ (day/night) (HIGUCHI et al., 1999). A possible explanation may be that cherimoya is more sensitive to $V_{\text {pdL }}$, however, this response is not observed for sugar-apple, which confirms that the cultivation of this species ever be conducted in tropical regions (HIGUCHI et al., 1998). 
The $A$ found in this study ranged from 2.52 to $8.31 \mu \mathrm{mol} \mathrm{CO} \mathrm{m}^{-2} \mathrm{~s}^{-1}$, showing typical characteristics of ' $\mathrm{C} 3$ ' metabolism plants, commonly with lower photosynthetic rates (DOUBNEROVÁ; RYSLAVÁ, 2011). The $A$ observed were similar to those shown by Núnez-Elisea et al. (1999) in other Annonaceae ('araticum-do-brejo', soursop, wild soursop, sugarapple and atemoya), which presented values between 3 to $6 \mu \mathrm{mol} \mathrm{CO} \mathrm{m}^{-2} \mathrm{~s}^{-1}$.

The $A$ and $E$ are not always dependent variables, as demonstrated in this study in 'araticumde-terra-fria' and 'araticum-mirim' kept in nursery, which had higher $A$, but smaller $E$ therefore the greater assimilation, in this case, was related the highest WUE and not to greater stomatal opening. This behavior was also found by Ojeda et al. (2004a) in seedlings of atemoya, by Higuchi et al. (1998) and Higuchi et al. (1999) in cherimoya and Ojeda et al. (2004b) in soursop.

Access to atmospheric $\mathrm{CO}_{2}$ by photosynthetic mesophyll cells occurs through the stomatal opening and affects $A, g_{\mathrm{s}}$ and $E$ (JENSEN et al., 2011). Then, when the treatment provides conditions of high $g_{s}$, the $A$ tends to be high, depending on the use of internal carbon for the synthesis of organic compounds, which keeps the variation of $\mathrm{CO}_{2}$ chemical gradient, ensuring its entry into the leaf (OP DE BEECK et al., 2010).

Moreover, the highest values of $C_{i}$ were detected in plants kept in warm houses, as in 'araticum-de-terra-fria', 'araticum-mirim' and 'biribá', due to low $A / C_{i}$. So, even with increasing $E$ and trend of greater stomatal opening, there was no increase in influx of $\mathrm{CO}_{2}$ on the leaf of plants grown at warm house, except 'araticum-mirim', which was similar between the different crop protections. The low $A / C_{\mathrm{i}}$ leads to low organic synthesis, and the $E$ increase leads to lower WUE (MAURINO; PETERHANSEL et al., 2010).

Another extremely important factor, with significant influence in Annonaceae, is the temperature of the root (OJEDA et al., 2004b). According to George; Nissen (1987), suboptimal and supraoptimal temperatures in root region, not only reduces photosynthesis, but also dry the mass production in Annona species, influencing the accumulation of reserves in the whole plant. Furthermore, the impact of suboptimal and supraoptimal temperatures in Annona root region depends on the species. This is proved in this study, since the plants grown in nursery showed more favorable soil temperature, increasing gas exchanges.
This pattern of response in plants may be due to inhibition by feedback in the source (leaves) resulted in a strong reduction of sink (slow growing root) (TAIZ; ZIEGER, 2010). Growth reduction caused by temperature is also associated with limited water absorption, which leads to lower ionic absorption (MIGLIACCIO et al., 2010). Ojeda et al. (2004a) affirm that Annonaceae native of tropical regions are less tolerant to damage the photosynthetic apparatus, with low photosynthesis to be grown in soils with cooler temperatures $\left(15-20^{\circ} \mathrm{C}\right)$.

Thus, we can conclude that the different types of crop protection had a direct influence on gas exchange and, consequently, under the development of these species. Nursery provided suitable conditions for 'araticum-de-terra-fria', 'araticum-mirim' and 'biribá', increasing their gas exchanges. To atemoya the best crop protection was the greenhouse. 

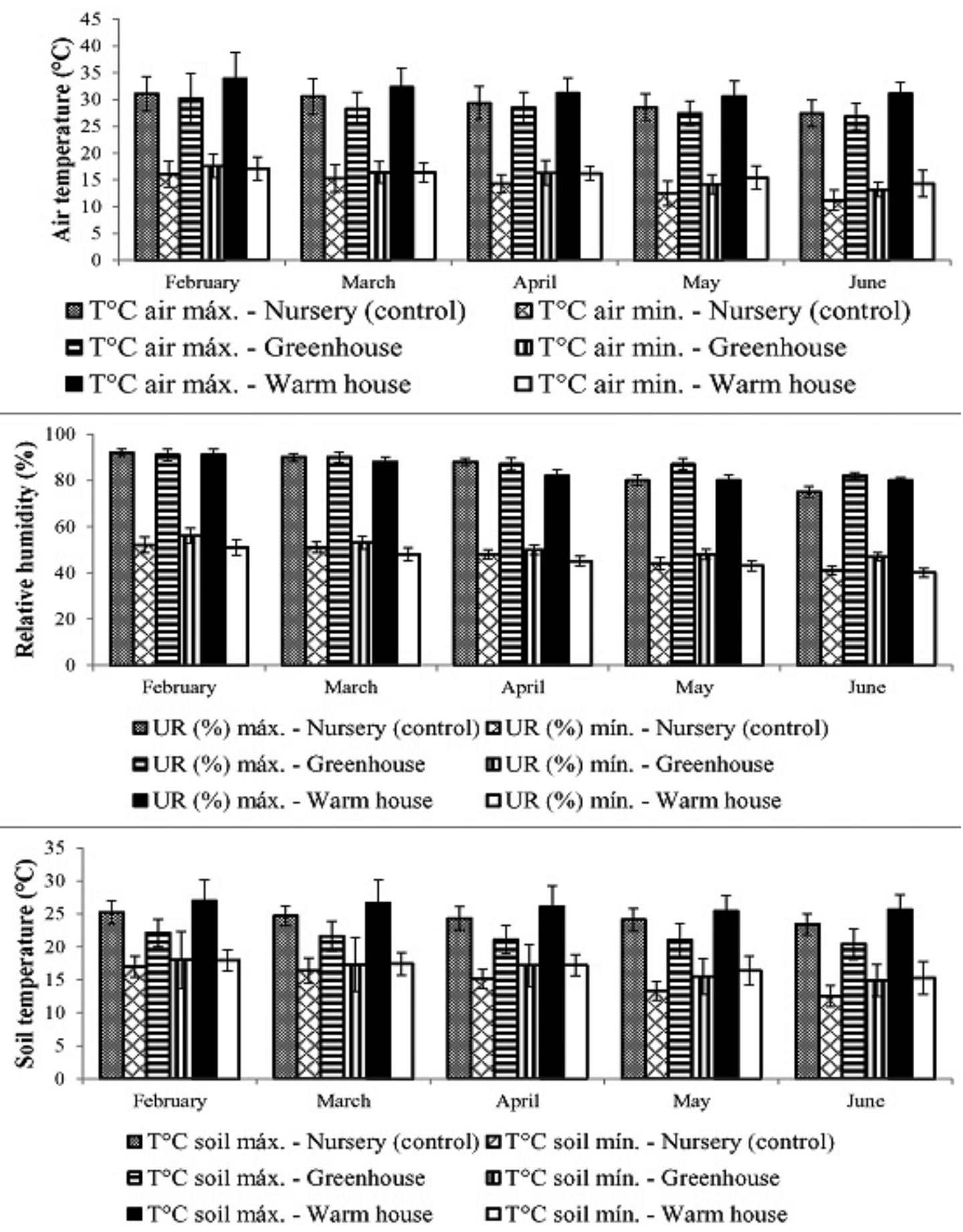

FIGURE 1- Environmental conditions obtained in different crop protections. Botucatu, UNESP, 2012. 


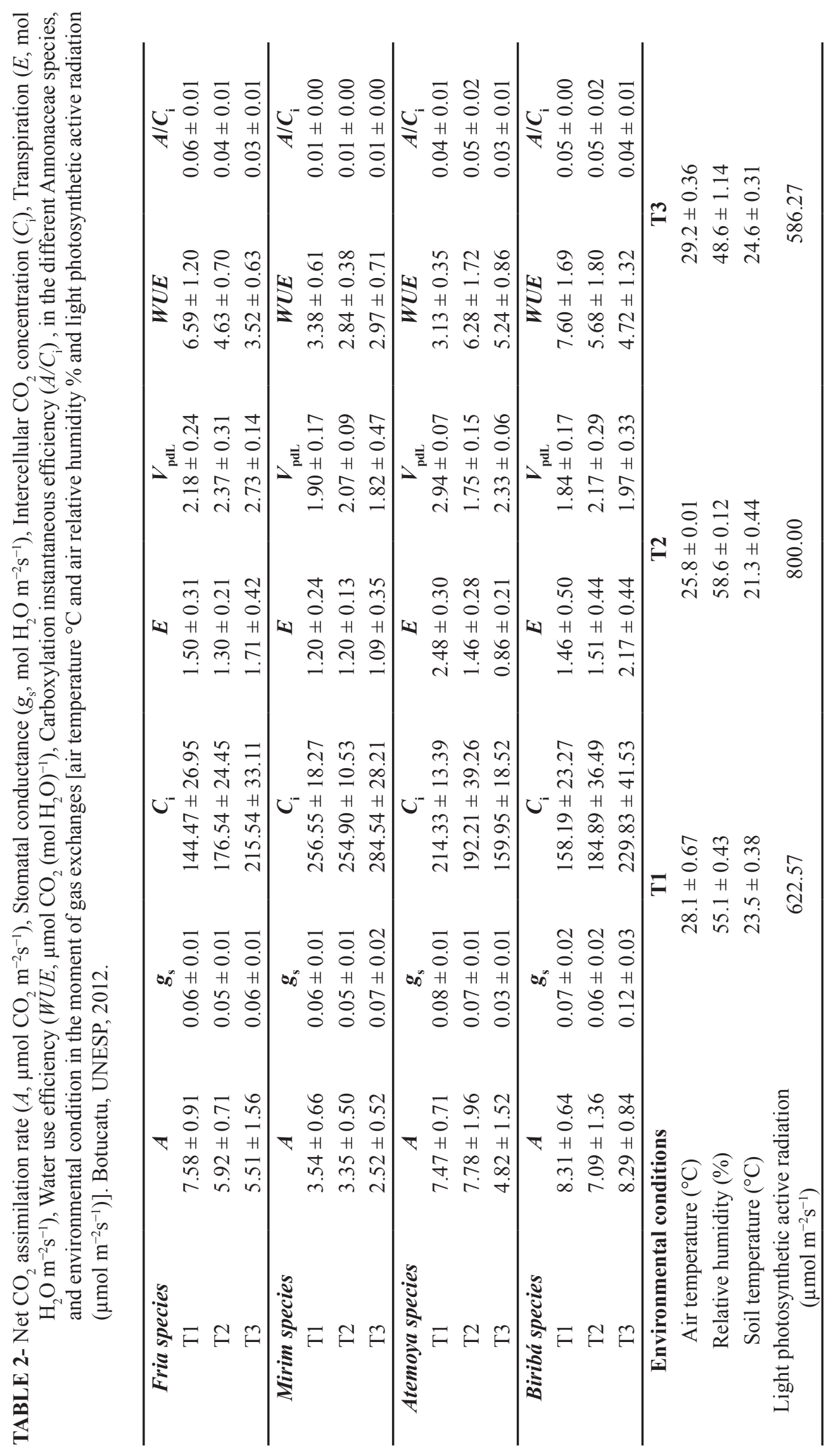




\section{ACKNOWLEDGMENTS}

The authors wish to thank the organization committee of the 'V International Congress and V Brazilian Meeting about Annonaceae: from gene to exportation' by funding the publication of this manuscript, and also to the Foundation for Research Support of the State of São Paulo (FAPESP), process Fapesp n ${ }^{\circ} 2011 / 00853-8$ for the scholarship granted.

\section{REFERENCES}

ALMEIDA, L.F.P. de; ALENCAR, C.M.de; YAMANISHI, O. K.I. Propagação por enxertia de atemóia 'Thompson' sobre espécies de Rollinia. Revista Brasileira de Fruticultura, Jaboticabal, v. 32, n. 2, p. 653-656, 2010.

BARON, D. et al. Evaluation of substrates on the emergence of "araticum-de-terra-fria" (Annona emarginata (Schltdl.) H. Rainer) seedlings. Revista Brasileira de Fruticultura, Jaboticabal, v. 33, n. 2, p. 575-586, 2011.

BARON, D. et al. Gas exchange, phisiological indexes and ionic accumulation in Annona emarginata (Schltdl.) H. Rainer seedlings in nutrients solution. Revista Brasileira de Fruticultura, Jaboticabal, v. 35, n. 2, p. 361-376, 2013.

DE CÁSSIA SEFFRIN, R. et al. Effects of crude seed extracts of Annona atemoya and Annona squamosa L. against the cabbage looper, Trichoplusia ni in the laboratory and greenhouse. Crop Protection, Guildford, v. 29, n. 1, p. 20-24, 2010.

DELIOPOULOS, T.; KETTLEWELL, P. S.; HARE, M. C. Fungal disease suppression by inorganic salts: A review. Crop Protection, Guildford, v. 29, n. 10, p. 1059-1075, 2010.

DOUBNEROVÁ, V.; RYŠLAVÁ. What can enzymes of $\mathrm{C} 4$ photosynthesis do for $\mathrm{C} 3$ plants under stress? Plant Science, Limerick, v. 180, p. 575, 2011.

GEORGE, A.P.; NISSEN, R.J. The effects of day/night temperatures on growth and dry matter production of custard apple (Annona cherimola $\times$ Annona squamosa) cultivar 'African Pride'. Scientia Horticulturae, Amsterdam, v. 31, n. 3-4, p. 269274, 1987.
HIGUCHI, H.; SAKURATANI, T.; UTSUNOMIYA, N. Photosynthesis, leaf morphology and shoot growth as affected by temperatures in cherimoya (Annona cherimola Mill.) trees. Scientia Horticulturae, Amsterdam, v. 80, n. 1-2, p. 91-104, 1999.

HIGUCHI, H.; UTSUNOMIYA, N.; SAKURATANI, T. Effects of temperature on growth, dry matter production and $\mathrm{CO}_{2}$ assimilation in cherimoya (Annona cherimola Mill.) and sugar apple (Annona squamosa L.) seedlings. Scientia Horticulturae, Amsterdam, v. 73, n. 2-3, p. 89-97, 1998.

JENSEN, A. M.; LÖF, M.; GARDINER, E. S. Effects of above- and below-ground competition from shrubs on photosynthesis, transpiration and growth in Quercus robur L. seedlings. Environmental and Experimental Botany, Elmsford, v. 71, n. 3, p. 367-375, 2011.

KAVATI, R.; WATANABE, H. S. Anonáceas. In: DONADIO, L.C. (Org.). História da fruticultura paulista. Jaboticabal: Sociedade Brasileira de Fruticultura, p. 35-4, 2010.

LEE, J.-S. Combined effect of elevated $\mathrm{CO}_{2}$ and temperature on the growth and phenology of two annual C3 and C4 weedy species. Agriculture, Ecosystems \& Environment, Amsterdam, v. 140, n. 3-4, p. 484-491, 2011.

MAURINO, V. G.; PETERHANSEL, C. Photorespiration: current status and approaches for metabolic engineering. Current Opinion in Plant Biology, Saint Louis, v. 13, n. 3, p. 248-255, 2010.

MIGLIACCIO, K. W. et al. Plant response to evapotranspiration and soil water sensor irrigation scheduling methods for papaya production in south Florida. Agricultural Water Management, Amsterdam, v. 97, n. 10, p. 1.452-1.460, 2010.

MAAS, P.J.M.; WESTRA, L.Y.T. Rollinia. Flora Neotropica Monograph, New York, v. 57, p. 1-188, 1992.

NÚNEZ-ELISEA, R. et al. Influence of flooding on net $\mathrm{CO}_{2}$ assimilation, growth, and stem anatomy of Annona species. Annals of Botany, London, v. 84, n. 6, p. 771-780, 1999. 
OJEDA, M.; SCHAFFER, B.; DAVIES, F.S. Flooding, root temperature, physiology and growth of two Annona species. Tree Physiology, Oxford, v. 24, n. 9, p. 1019-1025, 2004a.

OJEDA, M.; SCHAFFER, B.; DAVIES, F.S. Soil temperature, physiology, and growth of containerized Annona species. Scientia Horticulturae, Amsterdam, v. 102 , n. 2 , p. $243-255,2004$ b.

OP DE BEECK, M. et al. A comparison of photosynthesis-dependent stomatal models using twig cuvette field data for adult beech (Fagus sylvatica L.). Agricultural and Forest Meteorology, Amsterdam, v. 150, n. 4, p. 531-540, 2010.

PLAXTON, W.C.; PODESTÁ, F.E. The Functional Organization and Control of Plant Respiration. Critical Reviews in Plant Sciences, Apopka, v. 25, n. 2, p. 159-198, 2006.

RAINER, H. Monographics studies in the genus Annona L. (Annonaceae): Inclusion of the genus Rollinia A. St.-Hil. Annalen des Naturhistorischen Museums, Wien, v. 108B, p. 191-205, 2007.

SCALOPPI JÚNIOR, E.J. Propagação de espécies de Annonaceae com estacas caulinares. 2007. 92f. Tese (Doutorado) - Faculdade de Ciências Agronômicas e Veterinária, Universidade Estadual Paulista, Botucatu, 2007.
SCUC. Annona: Annona cherimola, A. muricata, $A$. reticulata, $A$. senegalensis and $A$. squamosa), Field manual for extension workers and farmers. Southampton: University of Southampton, 2006. 46p.

TAIZ, L.; ZEIGER, E. Plant physiology. $5^{\text {th }}$ ed. Sunderland: Sinauer Associates, 2010. 782p.

TOKUNAGA, T. A cultura da atemoia. Campinas: CATI, 2005. 80p. (Boletim Técnico, 233).

TORRES, L. M. A. R. et al. Effects of heat treatment and calcium on postharvest storage of atemoya fruits. Alimentos e Nutrição, Araraquara, v. 20, n. 3, p. 359-367, 2009.

VAN DONGEN, J. T. et al. Regulation of respiration in plants: A role for alternative metabolic pathways. Journal of Plant Physiology, Stuttgart, v. 168, n. 12, p. 1.434-1.443, 2011. 